\title{
Operative management of fragility fractures of the pelvis - a systematic review
}

Daniel G. G. Wilson ${ }^{1,2^{*}}$ D, Joshua Kelly ${ }^{1}$ and Mark Rickman ${ }^{1,3}$

\begin{abstract}
Background: The incidence of osteoporotic pelvic fractures in elderly patient is rising. This brings an increasing burden on health and social care systems as these injuries often lead to prolonged hospital admissions, loss of independence, morbidity and mortality. Some centres now advocate stabilisation of these injuries to reduce pain, facilitate early mobilisation, decrease hospital stay and restore independence. A systematic review of the literature was planned to establish the evidence for this intervention.

Methods: A systematic review was performed according to PRISMA guidelines. A clinical librarian performed a search of the following databases: NHS Evidence, TRIP, the Cochrane Database of Systematic Reviews, MEDLINE and EMBASE. Seventeen eligible studies were identified with 766 patients.

Results: The quality of evidence was poor with no good quality randomised trials. The majority of injuries were minimally displaced. Posterior ring injuries were most often stabilised with percutaneous screws which were sometimes augmented with void filler. A number of techniques were described for stabilisation of the anterior ring although fixation of the anterior ring was frequently not performed.

There was consistent evidence from the included studies that operative intervention significantly improved pain. Complications were minimal but there were increased failure rates when a single unaugmented sacroiliac joint screw was used. The limited availability of non-operative comparators made it difficult to draw firm conclusions about the efficacy of surgical over non-surgical management in these patients.

Conclusions: Operative management of fragility fractures of the pelvis should be considered for patients failing a brief period of non-operative management, however prospective randomised trials need to be performed to provide improved evidence for this intervention. Surgeons should consider which fixation techniques for fragility fractures of the pelvis are robust enough to allow immediate weightbearing, whilst minimising operative morbidity and post-operative complications.

PROSPERO Systematic Review ID: CRD42020171237.
\end{abstract}

Keywords: Osteoporosis, Pelvic fracture, Pelvic ring, Fragility fracture of the pelvis, Percutaneous

\footnotetext{
* Correspondence: d.wilson@doctors.org.uk

${ }^{1}$ Royal Adelaide Hospital, Port Road, Adelaide, SA 5000, Australia

2Present address: Brighton, UK

Full list of author information is available at the end of the article
}

(c) The Author(s). 2021 Open Access This article is licensed under a Creative Commons Attribution 4.0 International License, which permits use, sharing, adaptation, distribution and reproduction in any medium or format, as long as you give appropriate credit to the original author(s) and the source, provide a link to the Creative Commons licence, and indicate if changes were made. The images or other third party material in this article are included in the article's Creative Commons licence, unless indicated otherwise in a credit line to the material. If material is not included in the article's Creative Commons licence and your intended use is not permitted by statutory regulation or exceeds the permitted use, you will need to obtain permission directly from the copyright holder. To view a copy of this licence, visit http://creativecommons.org/licenses/by/4.0/. The Creative Commons Public Domain Dedication waiver (http://creativecommons.org/publicdomain/zero/1.0/) applies to the data made available in this article, unless otherwise stated in a credit line to the data. 


\section{Background}

The rising incidence of osteoporosis has brought significant challenges regarding the management of associated low energy injuries. In the past, high energy pelvic fractures associated with major trauma have predominated, however the incidence of low energy fragility fractures of the pelvis (FFP) is increasing and predicted to continue rising in the future [1-3].

High energy injuries often involve both the bony pelvis and associated ligaments and soft tissues. In contrast, low energy FFP are more commonly characterised by injuries affecting only the weaker osteoporotic bone. This observation is the basis for Rommen's classification which divides FFP into four groups of increasing instability ranging from isolated pubic rami injuries to complex bilateral displaced sacral injuries [4].

Historically the management of FFP in the elderly has involved a brief period of bed rest and analgesia followed by return to mobilisation as pain allowed $[5,6]$. Despite this, significant pain caused by the injury [7, 8] often leads to prolonged immobility [9]. The consequences of this in a vulnerable population are significant. The mortality rate is similar to hip fractures, there is significant associated morbidity, prolonged inpatient stay and patients often require temporary or permanent admission to nursing homes [3,10-15]. As with other debilitating osteoporotic fractures, this injury carries with it a significant financial burden [16] and results in a significant reduction in patient reported quality of life [17].

Some centres now advocate surgical management of these injuries to improve outcomes [18, 19]. The aim of this systematic review is to evaluate evidence for surgical management of FFP. This includes fracture patterns encountered as well as fixation methods and timing of interventions. We also aimed to identify whether these interventions improve pain and other outcomes such as mobility, length of stay, quality of life and mortality compared to conservatively managed patients.

\section{Methods}

This systematic review was registered with the International prospective register of systematic reviews (PROSPERO) Centre for Reviews and Dissemination, University of York and conducted in accordance with PRISMA guidelines [20]. A clinical librarian searched the followed databases; NHS Evidence, TRIP, the Cochrane Database of Systematic Reviews, MEDLINE and EMBASE. Bibliographic database searches were conducted using the NHS Evidence Healthcare Databases Advanced Search platform. The final search was conducted on 4th May 2020. Relevant natural language and controlled vocabulary terms were selected and combined, and final results reviewed. There were no language restrictions in the initial search, however studies not written in English were excluded.

All studies with fragility fractures of the pelvic ring including sacral insufficiency fractures were included in patients 60 years or older. Studies were excluded if they contained patients with high-energy injuries (defined as a fall greater than from standing height), or a pathological fracture from a cause other than osteoporosis. We also excluded patients managed with sacroplasty alone although included patients with augmentation of sacroiliac joint (SIJ) screws with bone cement or other void filler. Acetabular fractures and isolated iliac crest fractures were excluded as were studies with fewer than ten patients.

Abstracts were analysed by two authors (DW and JK). Relevant abstracts were selected for full text review and inclusion where relevant. Any disagreement on studies to include was decided by discussion and with the senior author (MR). A flowchart of the study selection can be seen in Fig. 1. Randomised and non-randomized studies were assessed for bias using The Cochrane Collaboration's tool for assessing risk of bias [21, 22] and case series assessed by the Joanna Briggs Institute checklist for case series [23]. Studies were assessed by two authors (DW and JK) and any disagreements resolved by discussion with a third (MR). A narrative synthesis was then performed using these tools. Main outcomes were pain scores, quality of life, mobility, length of stay and mortality. Secondary outcomes were complications including re-operations, failure of fixation, neurological deficits, and infection. No meta-analysis was planned.

\section{Results}

Seventeen studies were identified with 766 patients, of which 463 were managed operatively. One randomised study and three studies with non-operative comparison groups were identified. The remaining studies were case series. A summary of the results is presented in Table 1.

\section{Quality assessment}

Overall the quality of evidence for surgical management of FFP was low. The only randomised trial investigated the outcomes of FFP stabilised with transacral screw fixation with and without additional sacroplasty [25]. This non-blinded study also suffered from a high risk of selection bias, therefore drawing conclusions between the two groups was difficult. Despite this, robust follow-up and comprehensive reporting gave useful information regarding the pre and post-operative outcomes of surgically managed FFP.

The three comparative studies all suffered from high levels of bias. Groups were often poorly matched, had non-standardised interventions and suffered from incomplete follow up. All studies suffered selection bias as 


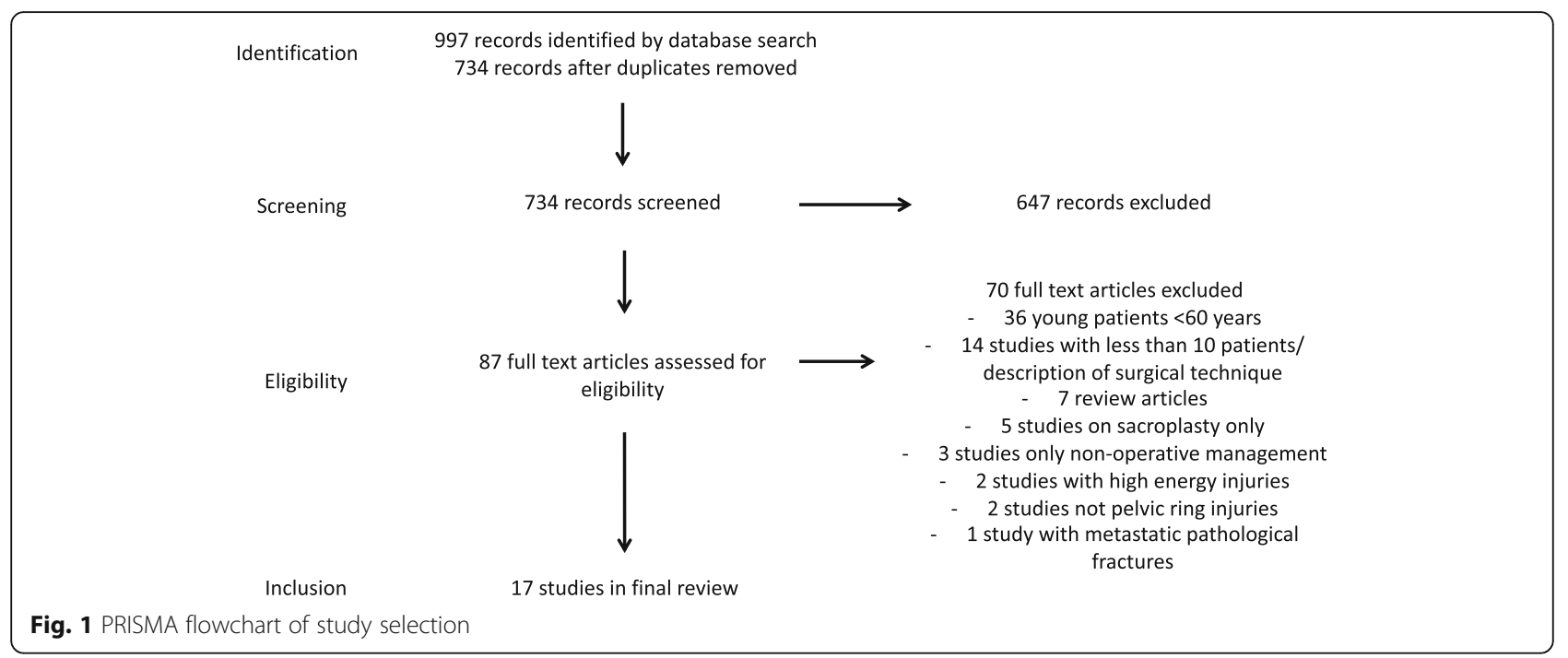

only patients in more significant pre-operative pain were selected for operative intervention. Whilst this may reflect a common scenario facing surgeons, drawing firm conclusions between the groups was difficult.

The quality of case series was variable. A common issue with the quality was a lack of pre-operative assessment of outcomes - particularly pain scores. Only six of the 13 case series contained pre-and post-operative/discharge pain scores for comparison. Most had some assessment of mobility or independence but these were often crude and unvalidated scoring systems and assessments that lacked a pre-operative comparison. Exclusion criteria, patient demographics and comorbidities were often poorly described or absent.

\section{Fracture patterns}

A number of classification systems were used to classify injuries including the Orthopaedic Trauma Association (OTA) [35], Young and Burgess [36] and Rommen's [4] classifications. Some studies did not utilise a recognised classification system and described fracture locations or grouped injuries as 'sacral insufficiency' fractures. This heterogeneity of fracture classifications made comparisons and analysis difficult between studies. Over $80 \%$ of the fractures studied consisted of minimally displaced unilateral or bilateral injuries suitable for percutaneous posterior fixation (Lateral compression type 1, Rommens Type II, OTA type B2). A minority of fractures were more displaced posterior unilateral fractures (5\%), Displaced bilateral fractures (5\%) and "Sacral U" type fractures (4\%). This distribution is similar to those previously described [4, 37].

\section{Fixation methods}

Numerous fixation methods were described for anterior and posterior ring injuries. Most patients underwent some form of posterior fixation. Only 26 (6\%) patients had anterior fixation alone.

\section{Posterior ring}

The majority of studies used percutaneous screws to fix posterior ring injuries. Figure 2 summarises the main methods of posterior fixation. $48 \%$ of patients had posterior stabilisation with a single screw whereas $36 \%$ had multiple screws. Most screws were SIJ screws crossing a single sacroiliac joint, however $23 \%$ of patients had longer transacral screws, passing from one side of the pelvis through both sacroiliac joints to the contralateral ilium $[8,25,27-30] .16 \%$ of patients received screw augmentation with polymethymethacralate (PMMA) or other void filler [8, 14, 32].

Around $25 \%$ of patients had a single, unaugmented SIJ screw. Eckardt examined reoperation rates for different screw configurations. They found a significantly increased reoperation risk when a single SIJ screw (not transacral or augmented) was used for posterior stabilisation regardless of whether the anterior ring was stabilised or not [29].

Two papers, with a total of $30(6 \%)$ patients, described the use of a percutaneous transacral bar $[18,34]$ to treat bilateral sacral fractures.

There was consistent evidence that pain scores were reduced post-operatively with any percutaneous posterior ring fixation.

Seven patients in one study had plate fixation for their iliac fractures without SIJ screws [33]. Five patients in two studies had their percutaneous screw fixation augmented with a posterior plate $[29,31]$ and seven patients in three studies had spinopelvic fixation [14, 24, 31]. This method of fixation was reserved for the most complex and displaced fractures, which were not suitable for other less invasive methods of fixation. 


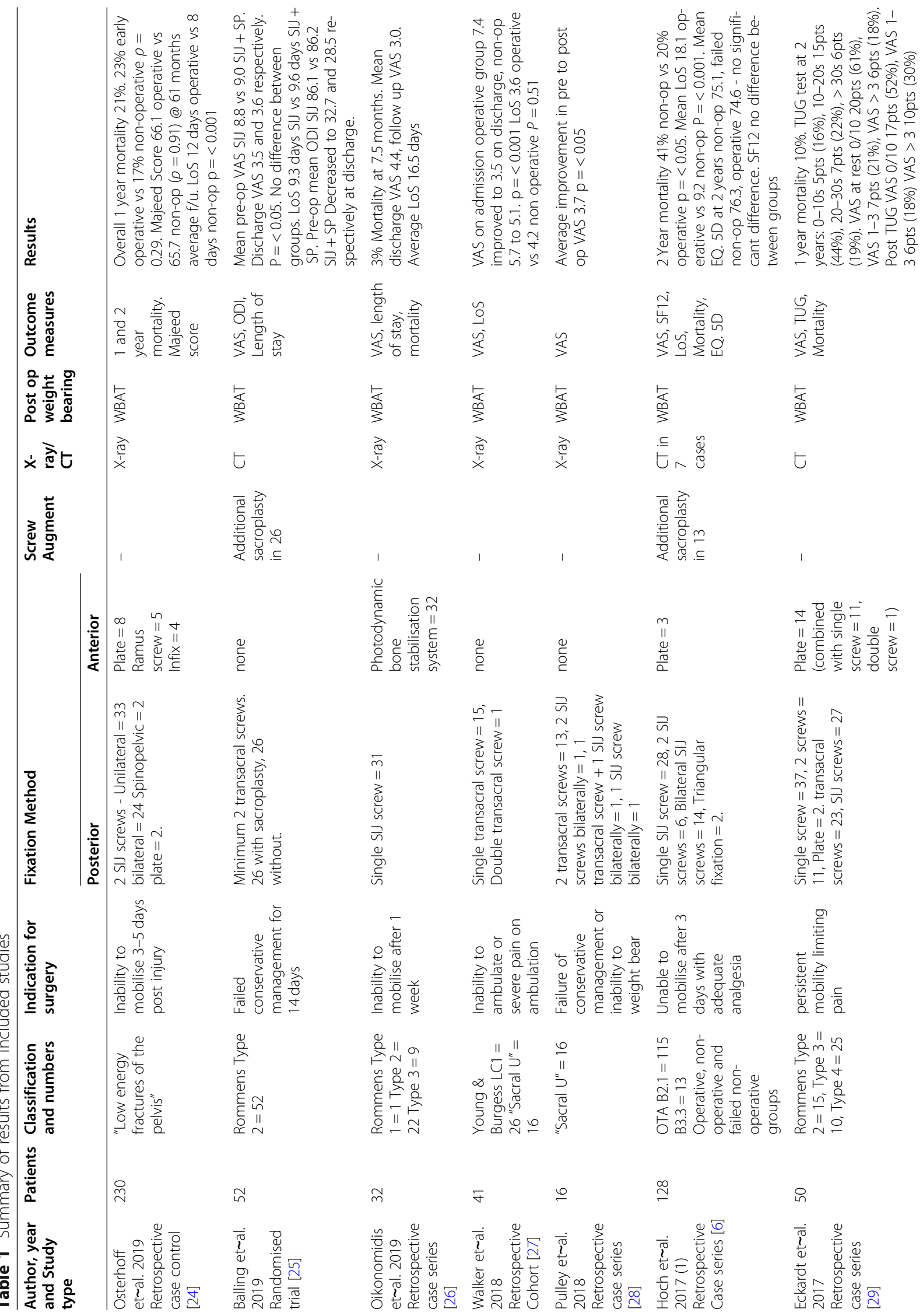




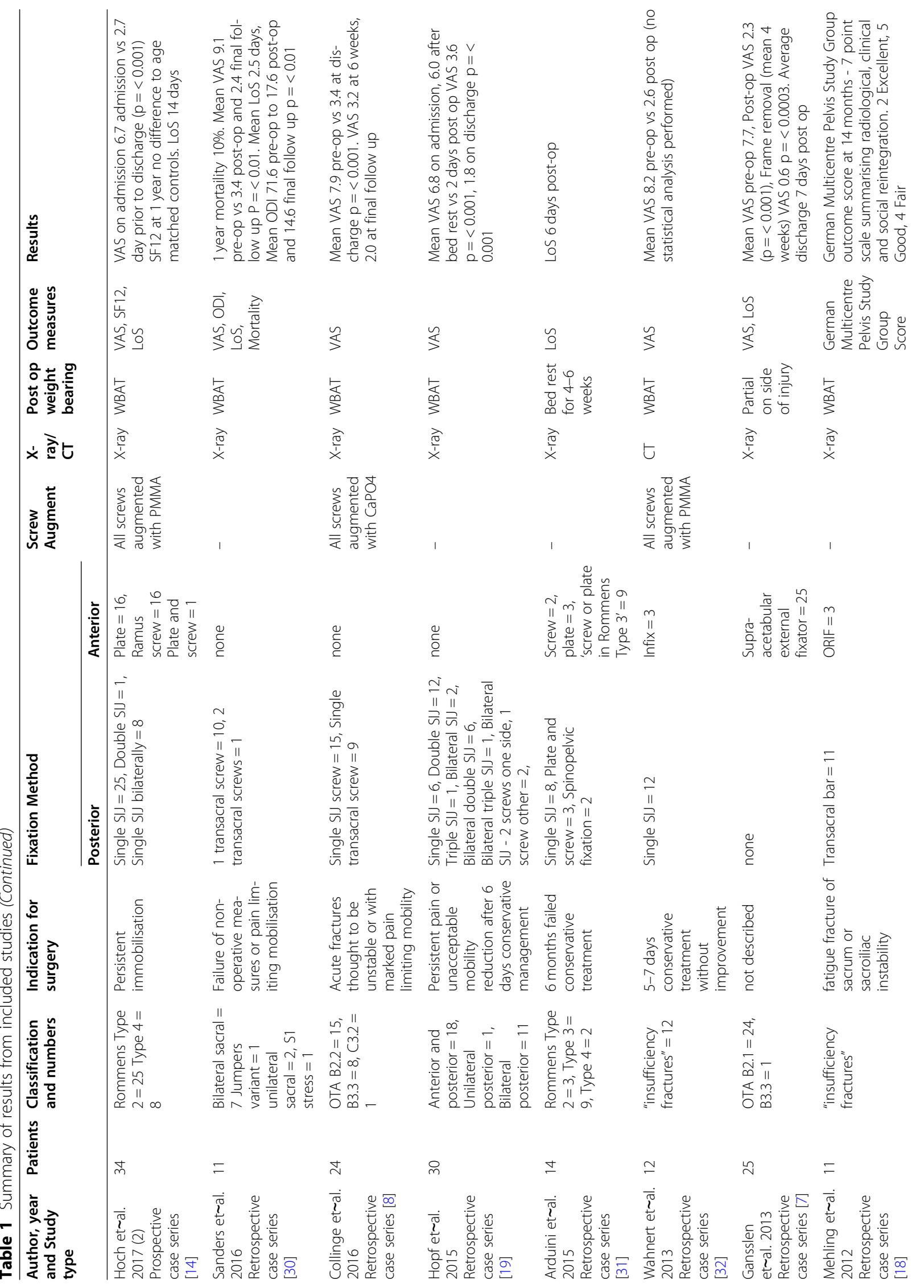




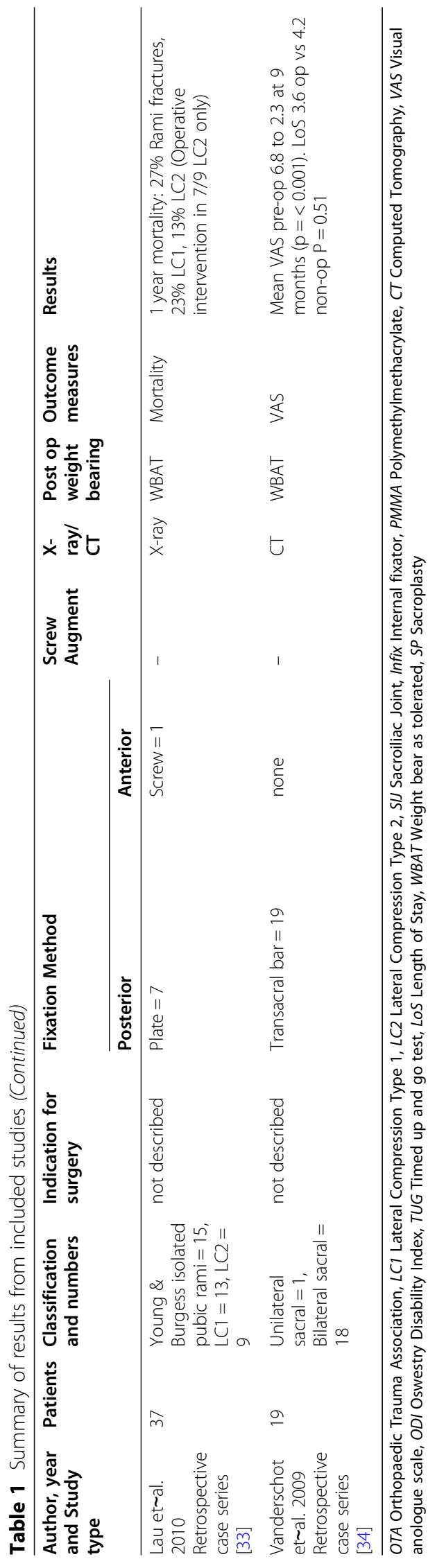




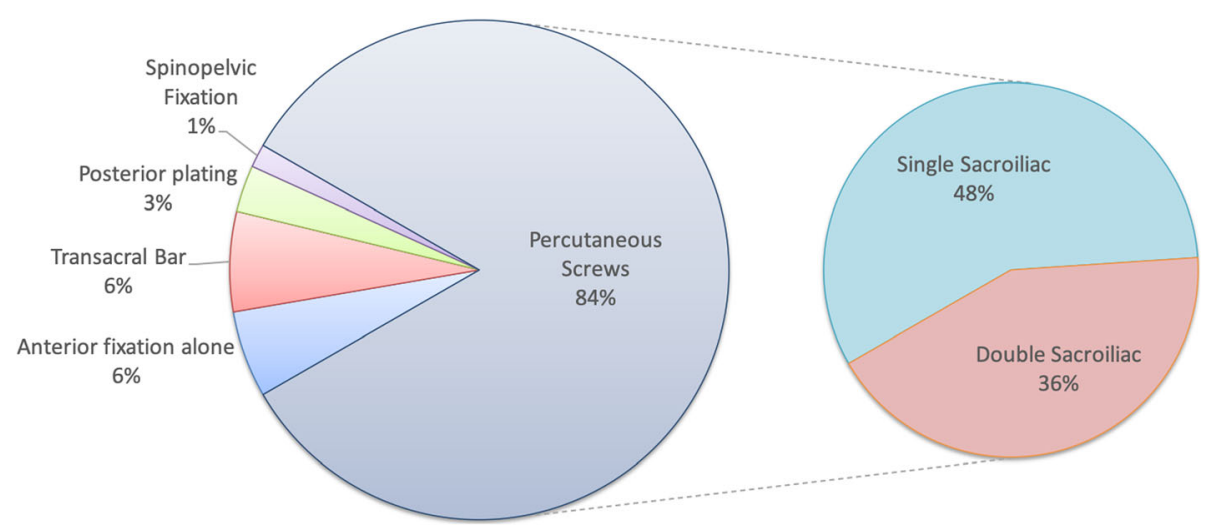

Fig. 2 Breakdown of posterior fixation strategies

\section{Screw augmentation}

Five studies used sacroplasty or screw augmentation. Balling et al. performed a prospective randomized study comparing a minimum of two transacral screws with and without PMMA sacroplasty. There was a statistically significant reduction in post-operative VAS scores and Oswestry Disability Index (ODI) scores in both groups but there was no difference between the groups.

Four other case series described screw augmentation. One utilised the technique in some patients but didn't comment on indications or analyse these patients separately [14]. The others all showed statistically significant improvements in post-operative pain scores. No screw loosening or failure was described in any study $[6,8,32]$.

\section{Anterior fixation}

Anterior fixation of the pelvic ring was variable. 322 (70\%) operatively managed patients had no anterior fixation. Seven studies did not utilise any form of anterior fixation $[8,19,25,27,28,30,34]$. Some chose to stabilise all the anterior ring injuries with either percutaneous screws or an open reduction and plate fixation [31]. Other studies performed selective fixation for more displaced injuries [6, 14]. One case series used external fixation alone for 4 weeks with significant decrease in post-operative pain [7]. Two studies used an anterior internal fixator (Infix) on seven patients of [24, 32]. Another used a photodynamic bone stabilization system to stabilise rami fractures with concurrent posterior screw fixation [26]. Overall there was no consensus regarding method or indication for anterior fixation.

\section{Pain}

Ten studies chose the Visual Analogue Scale (VAS) to quantify pain pre and post-operatively. Post-operative scores were either performed $24-48 \mathrm{~h}$ post-operatively or at discharge from hospital but in one case it was performed at an average of 9 months follow up [34]. All these studies in isolation showed a statistically significant improvement in average VAS scores. The average decrease in VAS amongst these studies was 4.5 which exceeds the minimally important clinical difference of 2.0 for patients with low back pain [38]. Only one study with a non-operative comparison group reported on pain pre-injury and on discharge. It showed a significant decrease in VAS from 7.4 pre-operatively to 3.5 in the operative group compared to the non-operative cohort who had an average VAS of 5.7 on admission and 5.1 on discharge. The operative patients had a significantly longer walking distance on discharge and $75 \%$ were discharged back home compared to $20 \%$ in the nonoperative group [27].

Three papers reported VAS post operatively at various timepoints but with no pre-operative comparison. All of these showed low VAS scores, which were comparable to the scores of other studies [14, 26, 29].

\section{Disability/mobility outcomes}

A broad selection of disability and quality of life scoring systems were used by authors. Two studies used the Oswestry Disability Index (ODI) questionnaire pre and post-operatively. The randomised study compared transacral screws with and without sacroplasty augmentation and showed a significant average improvement from 86.2 to 30.6 between pre and post-operative assessment but with no significant difference between the two cohorts [25]. One of the better quality case series also showed a significant average improvement from 71.6 to 17.6 after management with a single transacral screw [30]. SF12 and EQ-5D scores were reported in two studies and found no difference between uninjured comparisons at 1 year [6] or operatively and non-operatively managed patients at 2 years [14].

One retrospective case control study performed Majeed scores at an average of 61 months post 
operatively and found no significant difference (66.1 operative, vs 65.7 non-op $p=0.91$ ) [24].

Mehling et al. utilised a scoring system by the German Multicentre Pelvic Registry [39] which assesses radiographic, clinical and social reintegration domains. It reported 2 excellent, 5 good and 4 fair results at an average of 14 months follow up, but with no pre-operative comparison [18].

Most studies had an assessment of mobility or degree of post-operative independence. These are summarised in Table 2. Again there was significant heterogeneity in the method and timings of assessment, which made comparisons difficult. One of the cohort studies by Walker et al. showed significantly longer walking distances with operatively managed patients who were also more likely to be discharged home (75\% vs $20 \%)$ compared to non-operatively managed patients [27].

\section{Length of stay}

Walker et al. noted no significant difference in the length of stay between operative and non-operative groups (3.6 vs 4.2 days respectively) [27]. Hoch noted a significantly greater length of stay in operatively treated patients (18 days vs 9 days), although this did include an average of 6 days for an attempt at conservative management pre operatively [14]. Length of stay varied from an average of 2.5 to 16 days in the remaining studies reporting this outcome.

\section{Mortality}

Hoch et al. studied mortality rates at 2 years in three cohorts. They noted that 2-year mortality was significantly greater $(41 \%)$ in the non-operative group compared to the operative and failed non-operative groups (18 and $21 \%$ respectively) although the operative group was noted to be younger on average [14]. Another study comparing operative and non-operative groups showed no significant difference in mortality at 1 year $(23 \%$ vs $17 \% p=0.29$ ). It did however, show a survival benefit in the operative group develop after 2 years [24]. Reported 1 year mortality rates ranged from 10 to $27 \%$ in other studies.

\section{Complications}

Table 3 summarises the complications reported in the included studies. Operative complications were relatively uncommon. The main reasons for reoperation were for symptomatic screw loosening, incorrect screw placement

Table 2 Mobility/Independence Outcomes

\begin{tabular}{|c|c|c|c|}
\hline & & $\begin{array}{l}\text { Author/ } \\
\text { Year }\end{array}$ & Mobility/Independence \\
\hline $\begin{array}{l}\text { Osterhoff } \\
\text { et al. } 2019 \\
\text { [24] }\end{array}$ & $\begin{array}{l}36(24 \%) \text { patients returned home in operative group } \\
\text { compared to } 19(23 \%) \text { in non-operative group }\end{array}$ & $\begin{array}{l}\text { Sanders } \\
\text { et al. } 2016 \\
\text { [30] }\end{array}$ & $\begin{array}{l}\text { All patients returned to pre injury level of function at an } \\
\text { average } 625 \text { days of follow up }\end{array}$ \\
\hline $\begin{array}{l}\text { Balling et al. } \\
2019 \text { [25] }\end{array}$ & All patients discharged when able to mobilise upstairs & $\begin{array}{l}\text { Collinge } \\
\text { et al. } 2016 \\
{[8]}\end{array}$ & Not described \\
\hline $\begin{array}{l}\text { Oikonomidis } \\
\text { et al. } 2019 \\
{[26]}\end{array}$ & $\begin{array}{l}\text { Mobility at discharge: } 10(31 \%) \text { crutches, } 21(66 \%) \text { walker/ } \\
\text { rollator, } 1 \text { (3\%) unable to mobilise. Follow up at } 7 \text { months: } \\
11(34 \%) \text { independent, } 7(22 \%) \text { crutches, } 6(19 \%) \text { walker, } \\
1(3 \%) \text { immobile }\end{array}$ & $\begin{array}{l}\text { Hopf et al. } \\
2015 \text { [19] }\end{array}$ & Complete mobility regained in $73 \%$ at discharge \\
\hline $\begin{array}{l}\text { Walker et al. } \\
2018 \text { [27] }\end{array}$ & $\begin{array}{l}75 \% \text { patients discharged home in operative group } \\
\text { compared to } 20 \% \text { in non-operative group }(p=<0.001) \text {. } \\
\text { Significantly longer walking distance in operative vs non- } \\
\text { operative at discharge ( } 95.4 \text { vs } 35.2 \mathrm{ft} p=<0.01 \text { ) }\end{array}$ & $\begin{array}{l}\text { Arduini et al. } \\
2015 \text { [31] }\end{array}$ & $\begin{array}{l}\text { Bed rest } 4-6 \text { weeks post op. At } 6 \text { months } 11 \text { patients } \\
\text { (79\%) had normal mobility, } 1(7 \%) \text { single crutch, } 1 \text { (7\%) } \\
\text { two crutches }\end{array}$ \\
\hline $\begin{array}{l}\text { Pulley et al. } \\
2018[28]\end{array}$ & Average day 1 mobilisation $102 \mathrm{ft}$ & $\begin{array}{l}\text { Wahnert } \\
\text { et al. } 2013 \\
\text { [32] }\end{array}$ & $\begin{array}{l}\text { All patients could be mobilised to their pre-operative } \\
\text { levels }\end{array}$ \\
\hline $\begin{array}{l}\text { Hoch et al. } \\
2017 \text { (1) [6] }\end{array}$ & Not described & $\begin{array}{l}\text { Gansslen } \\
\text { et al. } 2013 \\
{[7]}\end{array}$ & $\begin{array}{l}24 \text { patients full mobility pre injury and } 1 \text { patient mobile } \\
\text { with walker. At discharge } 14(58 \%) \text { regained full mobility. } \\
7(28 \%) \text { partial weight bearing. } 21(88 \%) \text { patients regained } \\
\text { baseline mobility at frame removal (average } 4 \text { weeks) }\end{array}$ \\
\hline $\begin{array}{l}\text { Eckardt et al. } \\
2017 \text { [29] }\end{array}$ & $\begin{array}{l}73 \% \text { independent at home, } 13 \% \text { lost independence. } 60 \% \\
\text { Performed TUG test }<30 \text { s }\end{array}$ & $\begin{array}{l}\text { Mehling } \\
\text { et al. } 2012 \\
\text { [18] }\end{array}$ & Not described \\
\hline \multirow[t]{2}{*}{$\begin{array}{l}\text { Hoch et al. } \\
2017 \text { (2) [14] }\end{array}$} & $\begin{array}{l}\text { At } 1 \text { year } 9(26 \%) \text { patients mobile without aids, 6(18\%) } \\
\text { required } 1 \text { or } 2 \text { crutches, } 12 \text { (35\%) with walker }\end{array}$ & $\begin{array}{l}\text { Lau et al. } \\
2010[33]\end{array}$ & $\begin{array}{l}\text { At } 3 \text { months } 53 \% \text { baseline mobility isolated rami fractures, } \\
62 \% \text { LC1 and } 56 \% \text { LC2 fractures }\end{array}$ \\
\hline & & $\begin{array}{l}\text { Vanderschot } \\
\text { et al. } 209 \\
\text { [34] }\end{array}$ & $\begin{array}{l}5 \text { point } A D L \text { score used. Average } 3.26 \text { pre op improved to } \\
1.68 \text { at follow up }(P=<0.0001) \text { at an average of } 9 \text { months }\end{array}$ \\
\hline
\end{tabular}


Table 3 Complications and reoperations

\begin{tabular}{|c|c|c|c|}
\hline & $\begin{array}{l}\text { Reoperations } \\
\text { (\%) }\end{array}$ & Indications & Other \\
\hline $\begin{array}{l}\text { Osterhoff } \\
\text { et al. } 2019 \\
\text { [24] }\end{array}$ & $\begin{array}{l}\text { No reoperations } \\
\text { reported }\end{array}$ & - & $\begin{array}{l}\text { In hospital complications more common in } \\
\text { operative group (35\%) vs non-operative group } \\
(14 \%) p=<0.05\end{array}$ \\
\hline $\begin{array}{l}\text { Balling et al. } \\
2019 \text { [25] }\end{array}$ & $1(2 \%)$ & evacuation post op haematoma & $\begin{array}{l}1 \text { guidewire perforation into spinal canal, } 4 \text { cases } \\
\text { cement extrusion - } 2 \text { into canal, } 2 \text { into soft tissue. } \\
\text { All asymptomatic }\end{array}$ \\
\hline $\begin{array}{l}\text { Oikonomidis } \\
\text { et al. } 2019 \\
{[26]}\end{array}$ & $1(3 \%)$ & Implant failure requiring removal & 2 pneumonia, 4 UTI \\
\hline $\begin{array}{l}\text { Walker et al. } \\
2018 \text { [27] }\end{array}$ & $\begin{array}{l}\text { No reoperations } \\
\text { reported }\end{array}$ & - & $\begin{array}{l}1 \mathrm{Gl} \text { bleed in operative group. } 1 \mathrm{Gl} \text { bleed and } 2 \\
\text { COPD exacerbations in non-operative group. }\end{array}$ \\
\hline $\begin{array}{l}\text { Pulley et al. } \\
2018 \text { [28] }\end{array}$ & $\begin{array}{l}\text { No reoperations } \\
\text { reported }\end{array}$ & - & no complications \\
\hline $\begin{array}{l}\text { Hoch et al. } \\
2017 \text { (1) [6] }\end{array}$ & $4(13 \%)$ & 3 screw malposition, 1 revision for infection & $\begin{array}{l}2 \text { patients (4\%) required transfusion post op. } \\
\text { Medical complications } 8 \% \text { non-operative group, } \\
18 \% \text { operative group }\end{array}$ \\
\hline $\begin{array}{l}\text { Eckardt } \\
\text { et al. } 2017 \\
{[29]}\end{array}$ & $13(26 \%)$ & $\begin{array}{l}1 \text { screw malposition, } 1 \text { infection, } 9 \text { for symptomatic implant } \\
\text { loosening, } 2 \text { patients revised for implant loosening required } \\
\text { further revision for non-union }\end{array}$ & - \\
\hline $\begin{array}{l}\text { Hoch et al. } \\
2017 \text { (2) [14] }\end{array}$ & $2(6 \%)$ & 1 screw malposition, 1 evacuation haematoma & $\begin{array}{l}3 \text { asymptomatic PMMA leaks, } 1 \text { Pulmonary } \\
\text { embolism }\end{array}$ \\
\hline $\begin{array}{l}\text { Sanders } \\
\text { et al. } 2016 \\
\text { [30] }\end{array}$ & $\begin{array}{l}\text { No reoperations } \\
\text { reported }\end{array}$ & - & No complications \\
\hline $\begin{array}{l}\text { Collinge } \\
\text { et al. } 2016 \\
\text { [8] }\end{array}$ & $\begin{array}{l}\text { No reoperations } \\
\text { reported }\end{array}$ & - & $\begin{array}{l}1 \text { extravasation of calcium phosphate into } \\
\text { sacroiliac joint - asymptomatic }\end{array}$ \\
\hline $\begin{array}{l}\text { Hopf et al. } \\
2015[19]\end{array}$ & $3(10 \%)$ & 1 screw malposition, 2 evacuation haematoma & $\begin{array}{l}1 \text { intraoperative bleed requiring } 3 \text { units blood. } 2 \\
\text { cases HAP and } 2 \text { Cases UTI in } 3 \text { patients }\end{array}$ \\
\hline $\begin{array}{l}\text { Arduini } \\
\text { et al. } 2015 \\
{[31]}\end{array}$ & $\begin{array}{l}\text { No reoperations } \\
\text { reported }\end{array}$ & - & $\begin{array}{l}1 \text { intrapelvic iliac screw from spinopelvic fixation } \\
\text { - asymptomatic and left in situ }\end{array}$ \\
\hline $\begin{array}{l}\text { Wahnert } \\
\text { et al. } 2013 \\
{[32]}\end{array}$ & $\begin{array}{l}\text { No reoperations } \\
\text { reported }\end{array}$ & - & No complications \\
\hline $\begin{array}{l}\text { Gansslen } \\
\text { et al. } 2013 \\
\text { [7] }\end{array}$ & $\begin{array}{l}\text { No unplanned } \\
\text { reoperations } \\
\text { reported }\end{array}$ & $\begin{array}{l}\text { All patients required planned removal of external fixator in } \\
\text { outpatient setting }\end{array}$ & $\begin{array}{l}2 \text { pin site infections managed with antibiotics. } 1 \\
\text { pin loosening. }\end{array}$ \\
\hline $\begin{array}{l}\text { Mehling } \\
\text { et al. } 2012 \\
\text { [18] }\end{array}$ & $\begin{array}{l}\text { No reoperations } \\
\text { reported }\end{array}$ & - & 1 temporary L5 nerve palsy \\
\hline $\begin{array}{l}\text { Lau et al. } \\
2010[33]\end{array}$ & $\begin{array}{l}\text { No reoperations } \\
\text { reported }\end{array}$ & - & 1 fibrous non-union. 1 permanent L5 nerve palsy \\
\hline $\begin{array}{l}\text { Vanderschot } \\
\text { et al. } 2009 \\
\text { [34] }\end{array}$ & $2(11 \%)$ & 2 evacuation post op haematoma & - \\
\hline
\end{tabular}

with neurological symptoms and evacuation of postoperative haematoma. One study noted a significant rate of symptomatic screw loosening of $18 \%$ where a single percutaneous sacroiliac joint screw was used compared to two screws [29]. Two studies utilizing screw augmentation described a PMMA leak. In one paper there were 4 cases of PMMA extrusion, 2 into the spinal canal but with no symptoms [25]. Another noted asymptomatic PMMA leakage in $3(8 \%)$ of cases [6].

\section{Discussion}

Traditionally FFP have been managed non-operatively, often with a period of bed rest with analgesia and then mobilisation [5, 40]. Knowledge regarding the detrimental 
effect of bed rest and immobility in the elderly population has been present for decades [41]. Even short periods of immobilisation or decreased mobility lead to prolonged loss of muscle strength [42]. As a consequence there is reduced capacity to perform activities of daily living leading to loss of independence [43, 44]. Mortality from nonoperatively managed pelvic fractures is also similar to matched patients treated for hip fracture [45].

Elderly patients are unable to comply with restricted weightbearing regimes [46] - any management strategy should facilitate immediate full weight bearing with sufficient control of pain. This review highlights that whilst the quality of evidence for surgical fixation of FFP is poor, there is consistent data to support the idea that the majority of fracture patterns can be stabilised through minimally invasive methods, with a consequent reduction in pain. Whether this assertion is correct or if it translates to outcomes with regards mobility, length of stay, quality of life and mortality needs further investigation.

A heterogenous selection of fracture classifications were used by the studies, which made comparisons difficult. FFP often do not fit well into the OTA, Tile or Young and Burgess classifications as elderly patients tend to have bony injuries rather than ligamentous involvement $[4,8]$. Recognising this, the Rommen's classification was developed specifically for these injuries and may be more useful in classifying these injuries in the future [47].

The decision to pursue operative intervention in most of the studies was made after failure of conservative measures rather than based on fracture morphology. Whilst some unstable fractures may mandate surgical intervention, the commonest minimally displaced posterior injuries and even some more extensive and displaced injuries may be managed successfully with conservative measures. Conservative management was normally instituted for a period of 3-7 days although it did range up to 6 months. Given that relatively short periods of immobility can lead to significant morbidity we would suggest considering intervention after $48 \mathrm{~h}$ of failed conservative management and ideally within 1 week to avoid complications associated with prolonged immobility.

With regard to fixation techniques, when stabilising the posterior ring, the majority of authors utilised percutaneous posterior fixation where possible. Biomechanical studies have shown that two SIJ screws, a single augmented SIJ screw and a single transacral screw offer similar levels of stability and are all superior to single SIJ screw fixation in osteoporotic models [48-52]. There is some clinical evidence identified in this review that highlights a significantly increased rate of screw loosening when one unaugmented SIJ screw was used in isolation
[29]. This finding was independent of whether or not the anterior ring was stabilised. We would suggest that a single un-augmented SIJ screw may not provide sufficient stability in the osteoporotic patient to facilitate early full weightbearing and adequate pain relief. Either multiple screws, longer transacral screws, or screw augmentation should be considered. Surgeons should be mindful of the potential additional risks and benefits of each option.

Supplementary anterior fixation was sporadic if present and there was no correlation between lack of anterior fixation and overall fixation failure. Tile noted that the posterior ring contributes around $60 \%$ to pelvic stability [53] and Matta confirmed that even in unstable pelvic injuries rami fractures did not require stabilization by internal or external fixation when the posterior ring was stabilised [54]. The data presented here would support the assertion that posterior fixation in these injuries is more critical than anterior fixation. Stabilising the anterior ring contributes to overall pelvic stability and this may understandably be desirable to surgeons managing osteoporotic FFP. Percutaneous screw fixation of the ramus is an attractive option in minimally displaced fractures, however there is some biomechanical evidence in osteoporotic bone that plate fixation is superior to percutaneous retrograde screw fixation, the trade-off being that this requires an open approach [55]. External fixation is a quick and relatively easy technique but its use in the osteoporotic patient raises concerns with regard to pin-site infection, loosening and patient acceptance [4]. The Infix is a newer development and current trials are ongoing to identify whether it is a suitable method for stabilising osteoporotic type 1 lateral compression fractures [56], however its use is also not without complications [57]. A large study of the German pelvic database comparing Tile $\mathrm{B}$ and $\mathrm{C}$ type pelvic fractures with the anterior component involving the obturator foramen showed a higher rate of complications from more extensive anterior and posterior surgery compared to posterior stabilization alone with no difference in fixation failure or mortality [58]. When electing to stabilise FFP, surgeons should be mindful that supplementary anterior fixation may not be necessary with a robust posterior fixation. If electing to stabilise the anterior ring, surgeons should be mindful of potential complications associated with the chosen method. Anterior fixation alone may be appropriate depending on the strength of fixation and degree of posterior instability [7].

Observed complications from surgical interventions were low. Most studies used either computed tomography $(\mathrm{CT})$ guidance or fluoroscopy to insert screws. Incorrect screw placement was noted with both techniques but was infrequent and any iatrogenic 
neurological deficits resolved after removal and repositioning [6, 14, 19, 29].

We noted a previous systematic review of four studies on the effectiveness of surgical fixation of osteoporotic LC1 fractures. This found insufficient evidence to support guidance on the most effective treatment for patients sustaining this injury however where reported, mobility and function did improve after surgery [59]. This systematic review is a more comprehensive overview of 17 studies encompassing all types of FFP.

This systematic review does have some weaknesses. Firstly there was a lack of good quality randomised studies on which to base conclusions and most studies suffered from significant risk of bias. There was also significant heterogeneity in fracture classification and outcome measures. This made appropriate data pooling and analysis between studies difficult. We also excluded trials with less than 10 patients and excluded papers where an English translation could not be obtained. This only resulted in the loss of a small number of cases and therefore was unlikely to change the overall impression of the review.

\section{Conclusion}

This systematic review set out to identify the evidence for surgical management of FFP. Overall the quality of evidence was low. Of the 17 studies identified only one was randomised but with high risk of bias. Three studies were identified with a non-operative comparator group but all suffered from significant bias. Despite this, consistent improvement in pain and mobility was noted with stabilisation of the pelvis, which was most often performed percutaneously to the posterior ring. Anterior fixation of the pelvic ring was often absent and variable techniques were used when present. More than one SIJ screw posteriorly, longer transacral screws or screw augmentation offer more robust fixation than single SIJ screws for stabilising the pelvis, especially in the context of osteoporosis. Surgeons should consider operative stabilisation of FFP after a brief period of conservative management to avoid morbidity associated with immobility.

\section{Abbreviations \\ FFP: Fragility fracture of the pelvis; PROSPERO: International prospective register of systematic reviews; PRISMA: Preferred reporting instructions for systematic review and meta-analysis; NHS: National Health Service; SIJ: Sacroiliac Joint; OTA: Orthopaedic Trauma Association; \\ PMMA: Polymethylmethacrylate; VAS: Visual analogue scale; ODI: Oswestry Disability Index; CT: Computed tomography}

\section{Supplementary Information}

The online version contains supplementary material available at https://doi. org/10.1186/s12891-021-04579-w.

Additional file 1. Example of EMBASE search strategy.

\section{Acknowledgements}

The authors would like to acknowledge Tom Roper, Clinical Librarian, Brighton and Sussex University Hospitals NHS Trust for his assistance in conducting the literature search.

\section{Authors' contributions}

DW: methodology, search, study selection and analysis, writing and editing paper, read and approved manuscript. JK: study selection and analysis, writing and editing paper, read and approved manuscript. MR: concept, methodology, editing paper, study selection, read and approved manuscript. The author(s) read and approved the final manuscript.

\section{Funding}

No funding was received by any author for preparation of this manuscript.

Availability of data and materials

The datasets analysed and/or created where not presented are available from the corresponding author on reasonable request.

\section{Declarations}

Ethics approval and consent to participate

Ethical approval was not sought as this was a review of completed research studies with individual ethical approval.

\section{Consent for publication}

Not applicable.

\section{Competing interests}

The authors declare they have no competing interests.

\section{Author details}

${ }^{1}$ Royal Adelaide Hospital, Port Road, Adelaide, SA 5000, Australia. ${ }^{2}$ Present address: Brighton, UK. ${ }^{3}$ Centre for Orthopaedic and Trauma Research, University of Adelaide, Adelaide, SA 5005, Australia.

Received: 31 March 2021 Accepted: 2 August 2021

Published online: 21 August 2021

\section{References}

1. Boufous $S$, Finch $C$, Lord $S$, Close J. The increasing burden of pelvic fractures in older people, New South Wales, Australia. Injury. 2005;36(11):1323-9. https://doi.org/10.1016/J.INJURY.2005.02.008.

2. Rollmann MF, Herath SC, Kirchhoff F, Braun BJ, Holstein JH, Pohlemann T, et al. Pelvic ring fractures in the elderly now and then - a pelvic registry study. Arch Gerontol Geriatr. 2017;71:83-8. https://doi.org/10.1016/J.A RCHGER.2017.03.007.

3. Kannus P, Palvanen M, Niemi S, Parkkari J, Järvinen M. Epidemiology of osteoporotic pelvic fractures in elderly people in Finland: sharp increase in 1970-1997 and alarming projections for the new millennium. Osteoporos Int. 2000;11(5):443-8. https://doi.org/10.1007/s001980070112.

4. Rommens PM, Hofmann A. Comprehensive classification of fragility fractures of the pelvic ring: recommendations for surgical treatment. Injury. 2013; 44(12):1733-44. https://doi.org/10.1016/j.injury.2013.06.023.

5. Gotis-Graham I, McGuigan L, Diamond T, Portek I, Quinn R, Sturgess A, et al. Sacral insufficiency fractures in the elderly. J Bone Joint Surg Br. 1994;76B(6):882-6. https://doi.org/10.1302/0301-620X.76B6.7983111.

6. Höch A, Pieroh P, Henkelmann R, Josten C, Böhme J. In-screw polymethylmethacrylate-augmented sacroiliac screw for the treatment of fragility fractures of the pelvis: a prospective, observational study with 1year follow-up. BMC Surg. 2017;17(1):132. https://doi.org/10.1186/S12893-01 7-0330-Y.

7. Gänsslen A, Hildebrand F, Kretek C. Supraacetabular external fixation for pain control in geriatric type B pelvic injuries. Acta Chir Orthop Traumatol Cechoslov. 2013;80(2):101-5.

8. Collinge CA, Crist BD. Combined percutaneous lliosacral screw fixation with Sacroplasty using Resorbable calcium phosphate cement for osteoporotic pelvic fractures requiring surgery. J Orthop Trauma. 2016;30(6):e217-22. https://doi.org/10.1097/BOT.0000000000000520.

9. Kortebein P, Symons TB, Ferrando A, Paddon-Jones D, Ronsen O, Protas E, et al. Functional impact of 10 days of bed rest in healthy older adults. J 
Gerontol Ser A Biol Sci Med Sci. 2008;63(10):1076-81. https://doi.org/10.1 093/gerona/63.10.1076

10. Alnaib M, Waters S, Shanshal Y, Caplan N, Jones S, St Clair Gibson A, et al. Combined pubic rami and sacral osteoporotic fractures: a prospective study. J Orthop Traumatol. 2012;13(2):97-103. https://doi.org/10.1007/s10195-0120182-2.

11. van Dijk WA, Poeze M, van Helden SH, Brink PRG, Verbruggen JPAM. Tenyear mortality among hospitalised patients with fractures of the pubic rami. Injury. 2010;41(4):411-4. https://doi.org/10.1016/J.INJURY.2009.12.014.

12. Koval K, Aharonoff GB, Schwartz MC, Alpert S, Cohen G, McShinawy A, et al. Pubic rami fracture: a benign pelvic injury? J Orthop Trauma. 1997;11(1):7-9. https://doi.org/10.1097/00005131-199701000-00003.

13. Breuil V, Roux CH, Testa J, Albert C, Chassang M, Brocq O, et al. Outcome of osteoporotic pelvic fractures: an underestimated severity. Survey of 60 cases. Jt Bone Spine. 2008;75(5):585-8. https://doi.org/10.1016/J.JBSPIN.2008. 01.024.

14. Höch A, Özkurtul O, Pieroh P, Josten C, Böhme J. Outcome and 2-year survival rate in elderly patients with lateral compression fractures of the pelvis. Geriatr Orthop Surg Rehabil. 2017;8(1):3-9. https://doi.org/10.1177/21 51458516681142.

15. Fritz A, Gericke L, Höch A, Josten C, Osterhoff G. Time-to-treatment is a risk factor for the development of pressure ulcers in elderly patients with fractures of the pelvis and acetabulum. Injury. 2020;51(2):352-6. https://doi. org/10.1016/j.injury.2019.12.007.

16. Heinrich S, Rapp K, Rissmann U, Becker C, König H-H. Cost of falls in old age: a systematic review. Osteoporos Int. 2010;21(6):891-902. https://doi.org/10.1 007/s00198-009-1100-1.

17. Schmitz P, Lüdeck S, Baumann F, Kretschmer R, Nerlich M, Kerschbaum M. Patient-related quality of life after pelvic ring fractures in elderly. Int Orthop. 2019;43(2):261-7. https://doi.org/10.1007/s00264-018-4030-8.

18. Mehling I, Hessmann MH, Rommens PM. Stabilization of fatigue fractures of the dorsal pelvis with a trans-sacral bar. Oper Tech Outcome Injury. 2012; 43(4):446-51. https://doi.org/10.1016/j.injury.2011.08.005.

19. Hopf JC, Krieglstein CF, Müller LP, Koslowsky TC. Percutaneous iliosacral screw fixation after osteoporotic posterior ring fractures of the pelvis reduces pain significantly in elderly patients. Injury. 2015;46(8):1631-6. https://doi.org/10.1016/j.injury.2015.04.036.

20. Liberati A, Altman DG, Tetzlaff J, Mulrow C, Gøtzsche PC, et al. The PRISMA statement for reporting systematic reviews and meta-analyses of studies that evaluate healthcare interventions: explanation and elaboration. BMJ. 2009;339(jul21 1):b2700. https://doi.org/10.1136/bmj.b2700.

21. Higgins JPT, Altman DG, Gøtzsche PC, Jüni P, Moher D, et al. The Cochrane Collaboration's tool for assessing risk of bias in randomised trials. BMJ. 2011; 343(oct18 2):343. https://doi.org/10.1136/BMJ.D5928.

22. Sterne JA, Hernán MA, Reeves BC, Savović J, Berkman ND, et al. ROBINS-I: a tool for assessing risk of bias in non-randomised studies of interventions. BMJ. 2016;355:14919. https://doi.org/10.1136/bmj.i4919.

23. Moola S, Munn Z, Tufanaru C, Aromataris E, Sears K, et al. Joanna Briggs institute reviewers Maunal. In: Aromatis E, Munn Z, editors. Joanna Briggs institute reviewers manual; 2017. The Joanna Briggs Institute.

24. Osterhoff G, Noser J, Held U, Werner CML, Pape H-C, Dietrich M. Early operative versus nonoperative treatment of fragility fractures of the pelvis. J Orthop Trauma. 2019;33(11):e410-5. https://doi.org/10.1097/BOT. 0000000000001584 ,

25. Balling $\mathrm{H}$. Additional Sacroplasty does not improve clinical outcome in minimally invasive navigation-assisted screw fixation procedures for nondisplaced insufficiency fractures of the sacrum. Spine (Phila Pa 1976). 2019;44(8):534-42. https://doi.org/10.1097/BRS.0000000000002899.

26. Oikonomidis S, Alabsi A, Ashqar G, Graf M, Sobottke R. Intramedullary stabilization of pubic ramus fractures in elderly patients with a photodynamic bone stabilization system (IlluminOss). Geriatr Orthop Surg Rehabil. 2019;10:1-8. https://doi.org/10.1177/2151459318824904.

27. Walker JB, Mitchell SM, Karr SD, Lowe JA, Jones CB. Percutaneous TransiliacTranssacral screw fixation of sacral fragility fractures improves pain, ambulation, and rate of disposition to home. J Orthop Trauma. 2018;32(9): 452-6. https://doi.org/10.1097/BOT.0000000000001243.

28. Pulley BR, Cotman SB, Fowler TT. Surgical fixation of geriatric sacral U-type insufficiency fractures. J Orthop Trauma. 2018;32(12):617-22. https://doi. org/10.1097/BOT.0000000000001308.

29. Eckardt H, Egger A, Hasler RM, Zech CJ, Vach W, Suhm N, et al. Good functional outcome in patients suffering fragility fractures of the pelvis treated with percutaneous screw stabilisation: assessment of complications and factors influencing failure. Injury. 2017;48(12):2717-23. https://doi.org/1 0.1016/j.injury.2017.11.002.

30. Sanders D, Fox J, Starr A, Sathy A, Chao J. Transsacral-Transiliac screw stabilization: effective for recalcitrant pain due to sacral insufficiency fracture. J Orthop Trauma. 2016;30(9):469-73. https://doi.org/10.1097/BOT. 0000000000000596

31. Arduini $M$, Saturnino L, Piperno A, lundusi $R$, Tarantino U. Fragility fractures of the pelvis: treatment and preliminary results. Aging Clin Exp Res. 2015; 27(S1):61-7. https://doi.org/10.1007/s40520-015-0430-4.

32. Wähnert D, Raschke MJ, Fuchs T. Cement augmentation of the navigated iliosacral screw in the treatment of insufficiency fractures of the sacrum. A new method using modified implants. Int Orthop. 2013;37(6):1147-50. https://doi.org/10.1007/s00264-013-1875-8.

33. Lau T-W, Leung F. Occult posterior pelvic ring fractures in elderly patients with osteoporotic pubic rami fractures. J Orthop Surg. 2010;18(2):153-7. https://doi.org/10.1177/230949901001800205.

34. Vanderschot P, Kuppers M, Sermon A, Lateur L. Trans-iliac-sacral-iliac-bar procedure to treat insufficiency fractures of the sacrum. Indian J Orthop. 2009;43(3):245-52. https://doi.org/10.4103/0019-5413.53454.

35. Meinberg E, Agel J, Roberts C, Karam M, Kellam J. Fracture and dislocation classification compendium - 2018. J Orthop Trauma. 2018;32(1):S1-S10. https://doi.org/10.1097/BOT.0000000000001063.

36. Manson T, OToole RV, Whitney A, Duggan B, Sciadini M, et al. Youngburgess classification of pelvic ring fractures: does it predict mortality, transfusion requirements, and non-orthopaedic injuries? J Orthop Trauma. 2010;24(10):603-9. https://doi.org/10.1097/BOT.0b013e3181d3cb6b.

37. Rommens PM, Arand C, Hopf JC, Mehling I, Dietz SO, Wagner D. Progress of instability in fragility fractures of the pelvis: an observational study. Injury. 2019;50(11):1966-73. https://doi.org/10.1016/j.injury.2019.08.038.

38. Hägg O, Fritzell P, Nordwall A, Swedish Lumbar Spine Study Group. The clinical importance of changes in outcome scores after treatment for chronic low back pain. Eur Spine J. 2003;12(1):12-20. https://doi.org/10.1 007/s00586-002-0464-0.

39. Pohlemann T, Tosounidis G, Bircher M, Giannoudis P, Culemann U. The German multicentre pelvis registry: a template for an European expert network? Injury. 2007;38(4):416-23. https://doi.org/10.1016/j.injury.2007.01.007.

40. Babayev M, Lachmann E, Nagler W. The controversy surrounding sacral insufficiency fractures. Am J Phys Med Rehabil. 2000;79(4):404-9. https://doi. org/10.1097/00002060-200007000-00014.

41. Creditor MC. Hazards of hospitalization of the elderly. Ann Intern Med. 1993; 118(3):219-23. https://doi.org/10.7326/0003-4819-118-3-199302010-00011.

42. Hvid LG, Suetta C, Nielsen JH, Jensen MM, Frandsen U, Ørtenblad N, et al. Aging impairs the recovery in mechanical muscle function following 4days of disuse. Exp Gerontol. 2014;52:1-8. https://doi.org/10.1 016/j.exger.2014.01.012.

43. Bell KE, von Allmen MT, Devries MC, Phillips SM. Muscle disuse as a pivotal problem in sarcopenia-related muscle loss and dysfunction. J frailty aging. 2016:5:33-41. https://doi.org/10.14283/jfa.2016.78.

44. Sonn U. Longitudinal studies of dependence in daily life activities among elderly persons. Scand J Rehabil Med Suppl. 1996;34:1-35.

45. Reito A, Kuoppala M, Pajulammi H, Hokkinen L, Kyrölä K, Paloneva J. Mortality and comorbidity after non-operatively managed, low-energy pelvic fracture in patients over age 70: a comparison with an age-matched femoral neck fracture cohort and general population. BMC Geriatr. 2019; 19(1):315. https://doi.org/10.1186/s12877-019-1320-y.

46. Kammerlander C, Pfeufer D, Lisitano LA, Mehaffey S, Böcker W, Neuerburg C. Inability of older adult patients with hip fracture to maintain postoperative weight-bearing restrictions. J Bone Jt Surg. 2018;100(11):936-41. https://doi. org/10.2106/JBJS.17.01222

47. Pieroh P, Höch A, Hohmann T, Gras F, Märdian S, Pflug A, et al. Fragility fractures of the pelvis classification. J Bone Jt Surg. 2019;101(11):987-94. https://doi.org/10.2106/JBJS.18.00930.

48. Oberkircher L, Masaeli A, Bliemel C, Debus F, Ruchholtz S, Krüger A. Primary stability of three different iliosacral screw fixation techniques in osteoporotic cadaver specimens_-a biomechanical investigation. Spine J. 2016;16(2):22632. https://doi.org/10.1016/j.spinee.2015.08.016

49. König A, Oberkircher L, Beeres FJP, Babst R, Ruchholtz S, Link BC. Cement augmentation of sacroiliac screws in fragility fractures of the pelvic ring-a synopsis and systematic review of the current literature. Injury. 2019;50(8): 1411-7. https://doi.org/10.1016/j.injury.2019.06.025. 
50. van Zwienen CMA, van den Bosch EW, Snijders CJ, Kleinrensink GJ, van Vugt AB. Biomechanical comparison of sacroiliac screw techniques for unstable pelvic ring fractures. J Orthop Trauma. 2004;18(9):589-95. https://doi.org/1 0.1097/00005131-200410000-00002.

51. Suero EM, Greiner A, Becker CA, Cavalcanti Kußmaul A, Weidert S, Pfeufer D, et al. Biomechanical stability of sacroiliac screw osteosynthesis with and without cement augmentation. Injury. 2020. https://doi.org/10.1016/j.injury.2 020.01.043.

52. Osterhoff G, Dodd AE, Unno F, Wong A, Amiri S, Lefaivre KA, et al. Cement augmentation in sacroiliac screw fixation offers modest biomechanical advantages in a cadaver model. Clin Orthop Relat Res. 2016;474(11):252230. https://doi.org/10.1007/s11999-016-4934-9.

53. Vrahas M, Hern TC, Diangelo D, Kellam J, Tile M. Ligamentous contributions to pelvic stability. Orthopedics. 1995;18(3):271-4. https://doi.org/10.3928/014 7-7447-19950301-09.

54. Matta J. Indications for anterior fixation of pelvic fractures. Clin Orthop Relat Res. 1996;329:88-96. https://doi.org/10.1097/00003086-199608000-00011.

55. Acklin YP, Zderic I, Buschbaum J, Varga P, Inzana JA, Grechenig S, et al. Biomechanical comparison of plate and screw fixation in anterior pelvic ring fractures with low bone mineral density. Injury. 2016;47(7):1456-60. https:// doi.org/10.1016/j.injury.2016.04.013.

56. ISRCTN - ISRCTN16478561: Surgical vs conservative treatment of LC1 pelvic fractures in the elderly. http://www.isrctn.com/ISRCTN16478561. Accessed 28 May 2020.

57. Vaidya R, Woodbury D, Nasr K. Anterior subcutaneous internal pelvic fixation/INFIX. J Orthop Trauma. 2018;32(6):S24-30. https://doi.org/10.1097/ BOT.0000000000001248.

58. Schmal H, Froberg LS, Larsen M, Südkamp NP, Pohlemann T, et al. Evaluation of strategies for the treatment of type $B$ and $C$ pelvic fractures. Bone Joint J. 2018;100-B(7):973-83. https://doi.org/10.1302/0301-620X.100B7. BJJ-2017-1377.R1.

59. Booth A, Ingoe HMA, Northgraves M, Coleman E, Harden M, Kassam J, et al. Effectiveness of surgical fixation for lateral compression type one (LC-1) fragility fractures of the pelvis: a systematic review. BMJ Open. 2019;9(5): e024737. https://doi.org/10.1136/bmjopen-2018-024737.

\section{Publisher's Note}

Springer Nature remains neutral with regard to jurisdictional claims in published maps and institutional affiliations.

Ready to submit your research? Choose BMC and benefit from:

- fast, convenient online submission

- thorough peer review by experienced researchers in your field

- rapid publication on acceptance

- support for research data, including large and complex data types

- gold Open Access which fosters wider collaboration and increased citations

- maximum visibility for your research: over $100 \mathrm{M}$ website views per year

At BMC, research is always in progress.

Learn more biomedcentral.com/submissions 